\title{
Impact of front line demonstration of raised bed seed cum fertilizer drill on growth and yield of soybean (Glycine max L.) in Indore district of Madhya Pradesh
}

\section{Jitendra Singh, Archana Kumari, D.K. Mishra and Nitin Pachlaniya}

See end of the Paper for authors' affiliation Correspondence to :

Jitendra Singh Krishi Vigyan Kendra (K.G.N.M.T.), Kasturbagram, Indore (M.P.) India Email : jitendrasinghkgnmt@ gmail.com
ABSTRACT : The farmer's field front line demonstrations were conducted during Kharif season 2014 to 2016 for soybean crop to demonstrate raised bed seed cum fertilizer drill and simple seed drill. Raised bed seed cum fertilizer drill was found better in term of growth characters and yield of soybean in comparison with simple seed drill sowing machine. The net return is the best index of profitability of soybean crop and higher net return per ha of Rs. 25246 was recorded for soybean crop under raised bed seed cum fertilizer drill whereas lower net return per ha of Rs. 17410 was recorded under normal seed drill sowing and yield was found 1440 and $1191 \mathrm{~kg} / \mathrm{ha}$, respectively.

- KEY WORDS : Soybean, Raised bed, Front line demonstration, Growth character, Yield

- HOW TO CITE THIS PAPER : Singh, Jitendra, Kumari, Archana, Mishra, D.K. and Pachlaniya, Nitin (2018). Impact of front line demonstration of raised bed seed cum fertilizer drill on growth and yield of soybean (Glycine max L.) in Indore district of Madhya Pradesh. Internat. J. Agric. Engg., 11(1) : 205-209, DOI: 10.15740/HAS/IJAE/11.1/205-209. 